Journal of Biotechnology and Strategic Health Research

\author{
Research Article / Araştırma Makalesi
}

http://dergipark.org.tr/tr/pub/bshr

\title{
Tüberküloz Peritonit Tanısı ile Takip Edilen Olguların Değerlendirilmesi
}

\author{
Evaluation of Patients Followed with Diagnosis of Tuberculosis Peritonitis
}

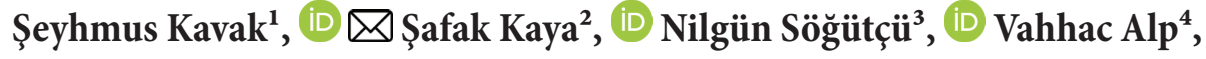 (iD) Dinçer Yıldırım ${ }^{5}$}

${ }^{1}$ Sağlık Bilimleri Üniversitesi, Gazi Yaşargil Eğitim Araştırma Hastanesi, Radyoloji Kliniği, Diyarbakır

${ }^{2}$ Sağlık Bilimleri Üniversitesi, Gazi Yaşargil Eğitim Araştırma Hastanesi, Enfeksiyon Hastalıkları Kliniği, Diyarbakır

${ }^{3}$ Sağlık Bilimleri Üniversitesi, Gazi Yaşargil Eğitim Araştırma Hastanesi, Patoloji Kliniği, Diyarbakır

${ }^{4}$ Sağlık Bilimleri Üniversitesi, Gazi Yaşargil Eğitim Araştırma Hastanesi, Genel Cerrahi Kliniği, Diyarbakır

${ }^{5}$ Sağlık Bilimleri Üniversitesi, Gazi Yaşargil Eğitim Araştırma Hastanesi, Jinekoonkoloji Kliniği, Diyarbakır

ORCID ID: Şeyhmus Kavak, https://orcid.org/0000-0002-5426-7478, Şafak Kaya, https://orcid.org/0000-0001-9912-7340,

Nilgün Söğütçü, https://orcid.org/0000-0002-2455-2964, Vahhac Alp, https://orcid.org/0000-0002-9504-5716,

Dinçer Ylldırım, https://orcid.org/0000-0002-7516-5972

^Sorumlu Yazar / Corresponding Author: Doç. Dr. Şafak Kaya, e-posta / e-mail: ksafak76@gmail.com

Geliş Tarihi / Received: 11-12-2020 Kabul Tarihi / Accepted: 20-12-2020 Yayın Tarihi / Online Published: 31-12-2020

Atıf Gösterimi/How to Cite: Kavak Ş., Kaya Ş., Söğütçü N., Alp V., Yıldır D. Tüberküloz Peritonit Tanısı ile Takip Edilen Olguların

Değerlendirilmesi, J Biotechnol and Strategic Health Res. 2020;4(3):328-332

\begin{tabular}{|c|c|}
\hline \multicolumn{2}{|l|}{ Özet } \\
\hline Amaç & $\begin{array}{l}\text { Son yllarda ekstrapulmoner tüberküloz olgularının pulmoner tüberküloz olgularına kıyasla arttığı gözlenmektedir. Pulmoner tüberkülozu olanlarda, ekstra } \\
\text { pulmoner tüberküloz asemptomatik olduğundan, intraabdominal ve gastrointestinal tüberkülozun gerçek insidansı bilinmemekle beraber tüberküloz peritonitin } \\
\text { nadir görüldüğünü bildiren çalışmalar mevcuttur. Tanısı atlanabilen ve erken tanı koyulmadığında morbiditesi ve mortalitesi artan bu hastalığın tanısında radyoloji } \\
\text { yol göstericidir. Biz bu çalışmada tüberküloz peritonitli olgularımızı hem epidemiyolojik, klinik, laboratuar bulguları ile irdelemeyi, hem de tanıda radyolojinin yol } \\
\text { gösterici olduğunu vurgulamayı amaçladık. }\end{array}$ \\
\hline Yöntem & $\begin{array}{l}\text { Bu çalışma, Ocak } 2012 \text {-Şubat } 2020 \text { tarihleri arasında hastanemizde tüberküloz peritonit tanısıyla takip edilen toplam } 23 \text { erişkin hastanın epidemiyolojik, klinik ve } \\
\text { laboratuar verisini içeren retrospektif bir çalşşmadır. Veriler hasta dosyalarından, hastane veri kayıt sisteminden elde edilmiștir. Elde edilen veriler sayı ve yüzdelik } \\
\text { hesaplama kullanılarak değerlendirilmiştir. }\end{array}$ \\
\hline Bulgular & 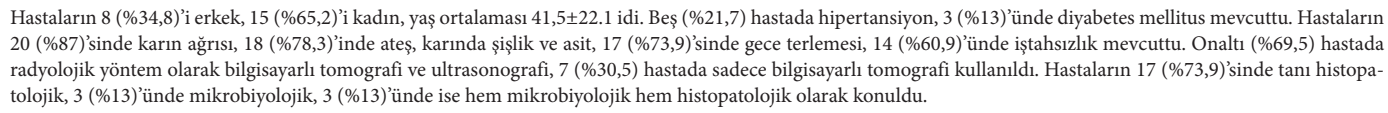 \\
\hline Sonuç & $\begin{array}{l}\text { Tüberküloz peritonit nadir görülen, belirti ve bulguları nonspesifik olduğundan kolayca atlanabilen bir hastalıktır. Erken tanı ve tedavi morbidite ve mortaliteyi } \\
\text { önlemek için önemlidir. Radyolojik bulgular tanıda oldukça yardımcıdır. Hem tüberküloz peritonit tanısı için düşündürücü bulguları göstermesi hem de asit sıvısı ve } \\
\text { periton incelemesi için ultrasonografi ve bilgisayarlı tomografi oldukça yol göstericidir. }\end{array}$ \\
\hline $\begin{array}{l}\text { Anahtar } \\
\text { kelimeler }\end{array}$ & Tüberküloz peritonit, Radyolojik, Ekstrapulmoner \\
\hline \multicolumn{2}{|l|}{ Abstract } \\
\hline Aim & $\begin{array}{l}\text { In recent years, it has been observed that extrapulmonary tuberculosis cases have increased compared to pulmonary tuberculosis cases. In patients with pulmonary tuberculosis, extra } \\
\text { pulmonary tuberculosis is asymptomatic, although the true incidence of intraabdominal and gastrointestinal tuberculosis is unknown, there are studies reporting that tuberculous peri- } \\
\text { tonitis is rare. Radiology guides the diagnosis of this disease, which can be missed and has increased morbidity and mortality when early diagnosis is not made. In this study, we aimed to } \\
\text { examine our patients with tuberculous peritonitis with epidemiological, clinical and laboratory findings and to emphasize that radiology is a guide in diagnosis. }\end{array}$ \\
\hline Methods & $\begin{array}{l}\text { This is a retrospective study including epidemiological, clinical and laboratory data of } 23 \text { patients who were followed up with the diagnosis of tuberculous peritonitis in our hospital } \\
\text { between January } 2012 \text { and February 2020. The data were obtained from patient files and hospital data recording system. The data obtained were evaluated using numbers and percentage } \\
\text { calculation. }\end{array}$ \\
\hline Results & $\begin{array}{l}8(34.8 \%) \text { of the patients were male, } 15(65.2 \%) \text { were female, the mean age was } 41.5 \pm 22.1 \text {. Five }(21.7 \%) \text { patients had hypertension and } 3(13 \%) \text { had diabetes mellitus. } 20(87 \%) \text { of the } \\
\text { patients had abdominal pain, } 18(78.3 \%) \text { had fever, abdominal swelling and acid, } 17(73.9 \%) \text { had night sweats, and } 14(60.9 \%) \text { had anorexia. Computed tomography and ultrasonograp- } \\
\text { hy were used as radiological methods in } 16(69.5 \%) \text { patients, and only computed tomography was used in } 7(30.5 \%) \text { patients. The diagnosis was made histopathologically in } 17 \text { (73.9\%) } \\
\text { of the patients, microbiological in } 3(13 \%) \text {, and both microbiological and histopathologically in } 3(13 \%) \text { patients. }\end{array}$ \\
\hline Conlusion & $\begin{array}{l}\text { Tuberculous peritonitis is a rare disease that can be easily overlooked because its signs and symptoms are nonspecific. Early diagnosis and treatment is important to prevent morbidity } \\
\text { and mortality. The radiological findings are very helpful in diagnosis. Ultrasonography and computed tomography are very guiding both for the diagnosis of tuberculous peritonitis and } \\
\text { for the examination of acid fluid and peritoneum. }\end{array}$ \\
\hline Ke & Iiological, Extrapulmonary \\
\hline
\end{tabular}




\section{Gİiş}

Tüberküloz, tüm dünyada özellikle gelişmekte olan ülkelerde hala önemini koruyan bir halk sağlığ sorunudur ${ }^{1}$. Daha önceleri akciğer tüberkülozu ön plandayken son yıllarda ekstrapulmoner tüberküloz olgularına daha sık rastlanmaktadır. Ekstrapulmoner tüberküloz, immünsuprese hastalarda daha sık gözlenmekte olup, olguların önemli bir kısmının HIV (Human Immunodeficiency Virus, İnsan İmmün Yetmezlik Virüsü) pozitif olduğu bildirilmiştir. Abdominal tüberküloz, periton, lenf bezi, ince bağırsak, kolon, mide ve diğer karın içi organların tüberkülozu şeklinde değişik formlarda gözlenebilir². Tüberküloz peritonit nadir görülen ekstrapulmoner tüberküloz formudur. Pulmoner ve ekstrapulmoner tüberküloz olguları arasında tüberküloz peritonit insidansı $\% 0,1$ ile $\% 0,7$ olarak belirtilmiş olup her iki cinste eşit oranda görülmektedir3. Kötü hijyen koşulları, yoğun populasyon ve pastörize edilmemiş süt içilmesi tüberküloz peritonit gelişiminde önemli risk oluşturur $^{3}$. Tüberküloz basili, periton boşluğuna bağırsak duvar yolu ile genital organlardan direkt olarak veya primer pulmoner odaktan hematojen yayılımla ulaşır. İntraabdominal birçok hastalık gibi semptom verdiğinden tanısında gecikmeler olabilmektedir. Başka bir deyişle hastalığın sinsi seyirli olması nedeniyle, tanısı klinik problem oluşturabilir. Hastalıktan şüphelenilmedikçe, tanı rahatlıkla atlanabilir veya gecikebilir ${ }^{4}$. Tanı ve dolayısıyla tedavisindeki gecikmeler nedeniyle morbidite ve mortalite de yüksektir ${ }^{5,6}$. Tanıda klinik ve radyolojik bulgular yol göstericidir. Radyolojik görüntülemenin yardımıyla son zamanlarda artan oranda periton biyopsisi alınmaktadır. $\mathrm{Bu}$ yöntem tanısal laparoskopiye oranla daha güvenli ve daha ucuz alternatif oluşturur ${ }^{7}$. Bu çalışmada nadir görülen bir hastalık olan tüberküloz peritonit tanısıyla takip ettiğimiz olguların epidemiyolojik, klinik, laboratuar verilerini sunmayı ve tanıda radyolojinin önemini vurgulamayı amaçladık.

\section{GEREÇ ve YÖNTEM}

$\mathrm{Bu}$ çalışma, Ocak 2012-Şubat 2020 tarihleri arasında hastanemizde tüberküloz peritonit tanısıyla takip edilen toplam 23 erişkin hastanın verisini içeren retrospektif bir çalışmadır. Veriler hasta dosyalarından, hastane veri kayıt sisteminden elde edilmiştir. Hastaların yaş, cinsiyet gibi demografik bilgileri, altta yatan hastalıkları, risk faktörleri, klinik özellikleri, laboratuar ve radyolojik bulguları, tedavi süreleri kaydedilmiştir. Çalışmaya dahil edilme kriterleri; 18 yaş üzerinde olmak ve mikrobiyolojik ve/veya histopatolojik olarak tüberküloz peritonit tanısı almak olarak belirlendi. Dışlama kriteri olarak ise 18 yaş altı olanlar ve mikrobiyolojik olarak negatif olup histopatolojik olarak malignite tanısı alanlar çalışma dışı bırakıldı. Veriler SPSS 16.0 programına yüklenip sayı ve yüzdelik hesaplama kullanılarak değerlendirilmiştir. Bu çalışma 28.02.2020 tarih ve 430 sayı numarası ile Sağlık Bilimleri Üniversitesi Gazi Yaşargil Eğitim Araştırma Hastanesi Etik Kurulu tarafından onaylanmıştır.

\section{BULGULAR}

Hastanemizde tüberküloz peritonit tanısıyla takip edilen toplam 23 hasta çalışmaya dahil edildi. Hastaların $8(\% 34,8)$ 'i erkek, 15 (\%65,2)'i kadındı. Yaş ortalaması 41,5 \pm 22.1 (Yaş aralığ1 16-86) idi. Beş (\%21.7) hastada hipertansiyon, 3 (\%13)'ünde diyabetes mellitus mevcuttu. Sadece bir hasta HIV pozitif, bir hasta böbrek nakil hastasıydı. Hastaların 3 (\%13)'ü steroid kullanıyordu. Olguların altta yatan hastalıkları ve risk faktörleri tablo 1'de gösterilmiştir. Hastaların 20 (\%87)'sinde karın ağrısı, 18 $(\% 78,3)$ 'inde ateş, karında şişlik ve asit, 17 (\%73,9)'sinde gece terlemesi, $14(\% 60,9)$ 'ünde iştahsızlık mevcuttu (Tablo 1). Hastaların $10(\% 43,5)$ 'unda tüberküloz öyküsü mevcuttu. Hastaların 17 (\%73,9)'sinde tanı histopatolojik, 3 (\%13)'ünde mikrobiyolojik, 3 (\%13)'ünde ise hem mikrobiyolojik hem histopatolojik olarak konuldu. Yine 16 $(\% 69,5)$ hastada radyolojik yöntem olarak bilgisayarlı tomografi (BT) ve ultrasonografi (USG), 7 (\%30.5) hastada sadece BT kullanıldı. Laboratuar değerlerine bakıldığında ortalama lökosit sayısı $10000 \pm 4746$, C reaktif protein (CRP) $72.7 \pm 53.5$, ortalama eritrosit sedimentasyon hizı (ESH) 44.3 \pm 18.9 idi (Tablo 2). Tedavide klasik 4'lü antitüberküloz tedavi kullanıldı. İkinci aydan sonra 2'li tedavi- 
ye geçilip toplamda 6 aya tamamlandı. Sadece iki hastada (biri HIV pozitif olan hasta diğeri böbrek transplantasyon hastası) tedavi 9 aya uzatıldı. İki hastada relaps gelişti.

\begin{tabular}{|l|l|}
\hline $\begin{array}{l}\text { Tablo 1. Tüberküloz peritonit nedeniyle takip edilen hastaların } \\
\text { demografik özellikleri, altta yatan hastalıkları, risk faktörleri } \\
\text { ve semptomları }\end{array}$ \\
\hline Değişken & N (\%) \\
\hline Yaş ortalaması \pm SD,y & $41.5 \pm 22.1$ \\
\hline Cinsiyet & \multicolumn{2}{|l}{} \\
\hline Erkek & $8(34.8)$ \\
\hline Kadın & $15(65.2)$ \\
\hline Altta yatan hastalık & \\
\hline Hipertansiyon & $5(21.7)$ \\
\hline Diyabetes mellitus & $3(13)$ \\
\hline Kronik akciğer hastalığı & $2(8.7)$ \\
\hline HIV & $1(4.3)$ \\
\hline Risk Faktörleri & $3(13)$ \\
\hline Steroid kullanımı & $3(13)$ \\
\hline Diyabetes mellitus & $1(4.3)$ \\
\hline Malignite & $1(4.3)$ \\
\hline HIV & $1(4.3)$ \\
\hline Böbrek nakli & $18(78.3)$ \\
\hline Semptom & $18(78.3)$ \\
\hline Karın ağrısı & $17(73.9)$ \\
\hline Ateş & $14(60.9)$ \\
\hline Karında şişlik & \\
\hline Asit & \\
\hline Kilo kaybı & \\
\hline Gece terlemesi & \\
\hline İstahsızlık & \\
\hline
\end{tabular}

Tablo 2. Tüberküloz peritonit hastalarının tanı, radyolojik ve laboratuar bulguları

\begin{tabular}{|l|c|}
\hline Değişken & N (\%) \\
\hline Tanı & $17(73.9)$ \\
\hline Histopatolojik & $3(13)$ \\
\hline Mikrobiyolojik & $3(13)$ \\
\hline Histopatolojik+Mikrobiyolojik & $16(69.5)$ \\
\hline Radyolojik Yöntem & $7(30.5)$ \\
\hline USG+BT & $10000 \pm 4746$ \\
\hline BT & $72.7 \pm 53.5$ \\
\hline Laboratuar & $44.3 \pm 18,9$ \\
\hline Kan lökosit düzeyi $\pm S D\left(m m^{3}\right)$ & \\
\hline C-reaktif protein (mg/dl) & \\
\hline Eritrosit sedimentasyon hizı (mm/h) & \\
\hline BT:Bilgisayarlı tomografi, USG: Ultrasonografi \\
\hline
\end{tabular}

\section{TARTIŞMA}

Tüberküloz peritonit en sık görülen abdominal tüberküloz formudur. Aktif pulmoner tüberkülozun hematojen yayılımı, komşu organ tüberkülozundan direkt yayılım ya da peritonda mevcut olan latent tüberkülozun reaktivasyonu sonucu gelişmektedir. Vakaların \%16’sında aktif tüberküloz odağı ile birliktedir8. Bizim takip ettiğimiz hastaların hiçbirinde aktif tüberküloz bulunmamaktadır. Genellikle 25-45 yaş arasında görülmektedir. Kadınlarda erkeklere nazaran daha fazla görülmektedir ${ }^{5}$. Bizim hasta grubumuzun yaş ortalaması $41.5 \pm 22.1$ ve literatürdeki gibi kadınlarda görülme sıklığı daha fazla olarak tespit edilmiştir. Sinsi gelişmektedir. Hastalar çoğunlukla karında şişlik (\%82), ateş (\%74), kilo kaybı (\%62) ve karın ağrısı (\%58) ile gelmektedir. Bizim hastalarımızda \%87 ile en fazla görülen semptom karın ağrısı, daha sonra ateş, karında şişlik, kilo kaybı olup asit hastaların \%78,3’ünde tespit edilmiştir.

Tüberküloz peritonitte en sık fizik muayene bulgusu asittir ve eş zamanlı akciğer tüberkülozu varlığı veya akciğer tüberkülozu geçirme öyküsü tanıda yardımcı olabilir ${ }^{9}$ Nitekim bizim hastalarımızın hemen yarısında tüberküloz geçirme öyküsü mevcuttur. Uzunköy ve ark'nın çalışmasında da 11 olgunun sadece l'inde aktif tüberküloz odağ1 bildirilmiştir ${ }^{8}$. 
Tüberküloz peritonitin laboratuar bulgularına bakıldığında anemi, ESH yüksekliği ve lökositozun olabileceği bildirilmektedir ${ }^{10}$. Bizim hastalarımızda ortalama lökosit düzeyi normal sınırlarda olup, ESH ve CRP değerleri yüksek olduğu tespit edilmiştir.

Radyolojik bulgular nonspesifik olmakla beraber tanıda yardımcıdır. Hem düşündürücü bulgular olması hem de asit sıvısı ve periton incelemesi için USG ve BT oldukça yol göstericidir. Ultrasonografide asit, kazeöz/kalsifiye lenf nodları tüberküloz peritoniti düşündüren bulgulardır. Tanının doğrulanmasında tomografi de yardımcı bir metoddur. Bilgisayarlı tomografide periton yüzeyinde minimal kalınlaşma ve abartılı kontrast tutulumu tüberküloz peritoniti akla getirir. Sıvı içinde fibriller veya ince septalar görülmesi karakteristiktir, fakat bu USG ile daha iyi değerlendirilebilir. Nodüllü veya nodülsüz peritoneal kalınlaşma, omental kalınlaşma veya kitle formasyonu, intestinal veya mezenterik yapışılılılar ve büyümüş lenf bezleri gözlenebilir ${ }^{11,12}$. Demirkazık ve ark.'nın yaptığ1 çalışmada asit bulgulu tüberküloz peritonitli olguların USG'sinde komplet veya inkomplet mobil septasyonlar, tomografilerinde periton kalınlaşması bildirilmiştir ${ }^{13}$. Bizim hastalarımızda da USG ve BT tanıda yardımcı olarak kullanılmıştır. USG veya BT eşliğinde periton biyopsisi tanıda yardımcıdır. Histolojik incelemenin yanısıra mikrobiyolojik inceleme için de örnek alınabilir ${ }^{14}$. Laparoskopi ile beraber biyopsi kesin ve hızlı tanıda önemlidir. Asitle beraber peritonda görülen nodüller ve tüberküller, periton ve organlar arasında yapışıklıklar, hemorajik alanlar tüberküloz peritoniti düşündürür. Bu görünüm sarkoidozla karışabilir fakat tüberkülozda kazeifikasyon olması ayırıcı tanıda önemlidir. Laparoskopi ile kesin teşhis konamayan ya da laparoskopinin riskli olduğu durumlarda laparotomi bir alternatif olarak kullanılabilir ${ }^{14-16}$. Bizim hastalarımızın 17(\%73,9)'sine laparotomi, 3(\%13) 'üne laparoskopi yapılıp 17(\%73,9)'sine histopatolojik, 3(\%13)'üne histopatolojik, 3(\%13)'üne ise hem histopatolojik hem de mikrobiyolojik tanı konulmuş olup mikrobiyolojik tanı koyma oranı düşüktür. Tedavinin erken başlanabilmesi mortalite ve morbiditenin önüne geçilebilmesi için önemlidir. Bu nedenle tanıda radyoloji hem akla gelmesi hem de tanı için gerekli örneğin alınabilmesi için gereklidir. Tedavi akciğer tüberkülozu gibidir ${ }^{17}$. Bizim hastalarımızın çoğunluğu 6 ay süre ile tedavi almıştır.

\section{SONUÇ}

Tüberkülozun endemik olduğu ülkelerde karın ağrısı, asit, ateş ile gelen hastalarda akla tüberküloz peritonit gelmeli, erken tedavi önemli olduğundan en kısa sürede tanıya gidilmelidir. Radyolojik bulgular nonspesifik olmakla beraber tanıda oldukça yardımcıdır. Hem tüberküloz peritonit tanısı için düşündürücü bulguları göstermesi hem de asit sıvısı ve periton incelemesi için ultrasonografi ve bilgisayarlı tomografi oldukça yol göstericidir. Çalışmamız hasta sayısının az olmasından dolayı kısıtlı olduğundan daha fazla sayıda hasta verisine sahip ileri çalışmalara ihtiyaç vardir.

\section{Çıkar çatışması yoktur.}


J Biotechnol and Strategic Health Res. 2020;4(3):328-332

\section{Kaynaklar}

1. Parter JDH, Mc Adam KPWJ. The re-emergence of Tuberculosis. Annu Rev Public Health 1994;15:303-23.

2. Bozer M, Coșkun A, Düzgün SA, Karaoğlanoğlu M. Abdominal tüberküloz ve klinik sunumları. MN Klinik Bilimler \& Doktor Cerrahi Tip Bilimleri Dergisi 2001;7:194-7.2002;8:43-8

3. Marshall JB. Tuberculosis of gastrointestinal tract and peritoneum. Am J Gastroenterol 1993;88:989-99.

4. Manohar A, Simjee AE, Haffejee AA, et al. Symptoms and investigative findings in 145 patients with tuberculous peritonitis diagnosed by peritoneoscopy and biopsy over a five years period. Gut 1990;31:1130-2.

5. Ahmad M, Ahmed A. Tuberculous peritonitis: Fatality associated with delayed diagnosis. South Med J 1999;92:406-8.

6. Julien TMY. Miscellaneous diseases of the peritoneum \& mesentery. In: Friedman SL, McQuaid KR, Grendell JH, eds. Current Diagnosis \& Treatment in Gastroenterology 2nd ed. New York: McGraw-Hill Companies; 2003; p.166-73.

7. Vardareli E, Kebapçi M, Sarıçam T, et al. Tuberculosus peritonitis of the wet ascidic type: clinical features, and diagnostic value of image-guided peritoneal biopsy. Dig Liv Dis 2004;36:199-204.
8. Uzunköy A, Nazlıgül Y. Tüberküloz Peritonit. Turkiye Klinikleri J Med Sci 2006; 26:404-408 9. Uzunkoy A, Harma M, Harma M. Diagnosis of abdominal tuberculosis: Experience from 11 cases and review of the literature. World J Gastroenterol 2004;10:3647-9.

10. Sharma MP, Bhatia V. Abdominal tuberculosis. Indian J Med Res 2004;120:305-15.

11. Sinan T, Sheikh M, Ramadan S, Sahwney S, Behbehani A. CT features in abdominal tuberculosis: 20 years experience. BMC Med Imaging 2002;2:3.

12. Machado N, Grant CS, Scrimgeour E. Abdominal tuberculosis- experience of a university hospital in Oman. Acta Trop 2001;80:187-90.

13. Demirkazı FB, Akhan O, Özmen MN, Akala D: US and CT findings in the diagnosis of tuberculous peritonitis. Acta Radiol 1996; 100 (2): 517- 20.

14. Chow KM, Chow VC, Szeto CC. Indication for peritoneal biopsy in tuberculous peritonitis. Am J Surg 2003;185:567-73..

15. Kharrat J, Gargouri D, Ouakaa A, et al. Laparoscopic aspects of peritoneal tuberculosis. Report of 163 cases. Tunis Med 2003;81:558-62.

16. Mimica M. Usefulness and limitations of laparoscopy in the diagnosis of tuberculous peritonitis. Endoscopy 1992;24:588-91.

17. Akgün Y, Yllmaz G, Taçyıldız İ. İntestinal ve peritoneal tüberküloz. Ulus Travma Derg 